\title{
Predator induced colour polymorphism in Danaus plexippus L. (Lepidoptera: Nymphalidae) in Hawaii
}

\author{
John Stimson and \\ Mark Berman
}

Zoology Department, University of Hawaii, Honolulu, H.I. 96822, U.S.A.

On the island of Oahu, Hawaii, the Monarch butterfly, Danaus plexippus (Lepidoptera: Nymphalidae) has two distinct and genetically determined wing-colour morphs, white and orange. The white morph has increased in frequency in the last 20 years, perhaps because of the predation on the orange form by the introduced birds Pycnonotus jacosus and Pycnonotus cafer, bulbuls. These birds are the only insect-eaters whose distributions coincide with that of white monarchs in Hawaii. The birds are not deterred by the cardiac glycosides in the monarchs' tissues. The orange form may be at greater risk of predation because it stands out against the foliage and infloresences of the milkweeds where the butterflies oviposit and feed in large numbers, and where predation commonly occurs. Several observations are consistent with the hypothesis that whites are more cryptic. $\mathbf{A}$ larger proportion of white butterflies are captured by netting at a particular time than eclose during the same period. Secondly, monarch wings found on the ground at the study sites and presumably broken off by the predators were almost all orange, again suggesting that the risk of predation is lower for white individuals. Lastly, the three other major Hawaiian islands which have been surveyed have orange monarchs but lack both bulbuls and white monarchs. These results suggest bulbuls exert a strong selection against the orange morph and are probably the cause of the increase in frequency of the white morph.

\section{INTRODUCTION}

Many adult lepidoptera, including species of the family Nymphalidae (Owen and Chanter, 1968; Smith, 1975a; Stimson and Meyers, 1984; Ackery and Vane-Wright, 1984) show colour polymorphism. Most cases involve a fairly simple mode of inheritance, often alternate alleles at a single locus. The mechanism by which the polymorphism develops or is maintained is often not clear although a variety of mechanisms have been proposed (Kettlewell, 1955; Gerould, 1923; Gordon, 1987; Owen and Chanter, 1971; Smith, 1973).

Danaus plexippus on Oahu, Hawaii, has been recognized to be dimorphic for wing colour for approximately the last 23 years. In 1958 an extensive monograph on Hawaii's insects made no mention of the white morph (Zimmerman, 1958). In 1965 Mitchell found that the white morph constituted $<1$ per cent of a large collection made on Oahu (Mitchell, 1966), but by 1984 the white morph constituted approximately 5 per cent of the Oahu population (Stimson and Meyers, 1984).

The white butterflies are homozygous recessive at a wing-colour locus (Stimson and Meyers, 1984).
They have white scales in place of orange on both surfaces of all wings. White $D$. plexippus are rare in mainland United States populations (Stimson and Meyers, 1984), possibly because predators mistake them for palatable butterflies, rather than distasteful monarchs. The distastefulness of monarchs is generally attributed to the sequestration of host-plant cardiac glycosides in the insects' tissues (Parsons, 1965; Reichstein et al., 1968). In Hawaii, the levels of cardiac glycosides in the tissues of the monarch are evidently low (Stimson and Meyers, 1984) and both colour forms are taken by predators.

In the late 1960 s or early 1970 s the white morph attained frequencies too high to be accounted for by mutation and thus indicative of a polymorphism. It is not known why the white morph began to increase during this period or why its frequency has increased since then. This study examines the pattern of increase in more detail and examines whether the frequency of the white individuals differs between collection sites, differs between phases of the annual cycle (Etchegaray and Nishida, 1975; Semble, 1980) or differs between age classes of monarchs produced in a season. In 
particular the study considers the possible role of avian predators in the appearance of the white morph and in causing the increase in its frequency.

\section{MATERIALS AND METHODS}

We assessed the frequency of the two morphs in local populations by collecting pupae and keeping them in cages until eclosion. On its eclosion, the morph and sex of each adult was scored, its wing was marked to indicate the place and date of collection and it was then released at the site of collection. Pupae were usually collected from milkweed bushes, Calotropis gigantea, or from adjacent structures. The bushes are usually $2-3 \mathrm{~m}$ tall and approximately $1-2 \mathrm{~m}$ in diameter. Five sites were sampled on the island of Oahu, Hawaii (fig. 1). Samples have been taken on the University of Hawaii campus at Manoa since 1972. Beginning in the $1987 / 1988$ season, collections of late larval instars and pupae were made at several additional sites on the island of Oahu: Kuliouou, $8 \mathrm{~km} \mathrm{SE}$ of campus; Waimanalo, $11 \cdot 2 \mathrm{~km} \mathrm{NE}$ of campus; Nanakuli, $40 \mathrm{~km} \mathrm{NW}$ of campus and Punaluu, $27 \mathrm{~km} \mathrm{NNW}$ of campus.
On some occasions in 1988 and 1989 the adults flying at a site were exhaustively collected with a hand net and retained. At the conclusion of collection, all the adults were scored for sex and colour morph, marked to indicate the day and place of collection, and then released.

At all sites where it was feasible, the ground and grass under and near milkweed bushes was searched for the wings of monarchs which had been torn from the bodies by predatory birds, bulbuls, of the genus Pycnonotus. The wings were frequently torn or punctured. None of the wings were curled or deformed, suggesting that they were the wings of actively flying monarchs and not the wings of individuals which were newly emerged, unsuccessful in emerging or deformed.

\section{RESULTS}

At the campus site there is an annual cycle in the abundance of monarchs beginning in November or December, peaking in December, January or February, and declining during the spring months (fig. 1, table 1). Larvae, pupae, or adults are

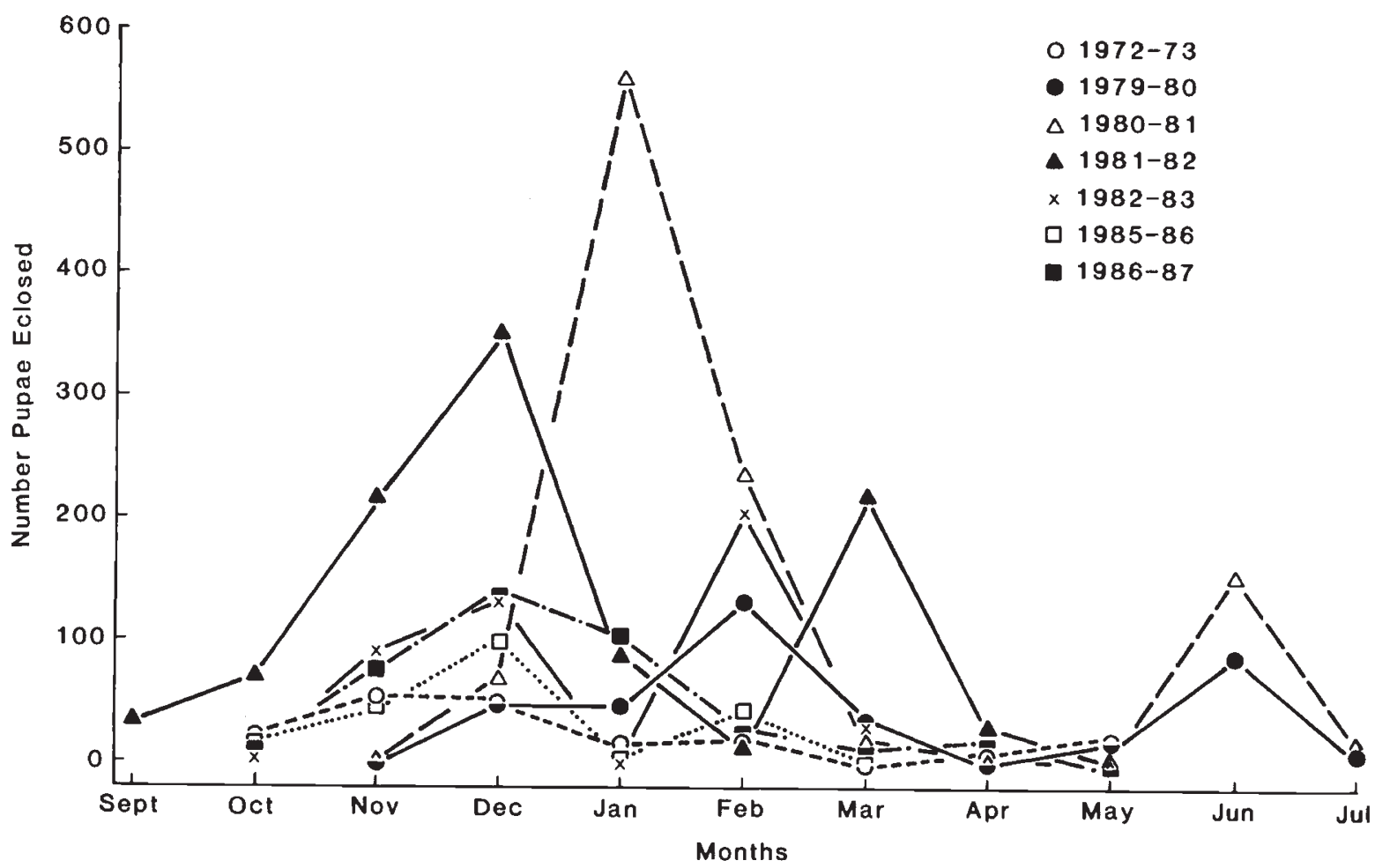

Figure 1 The annual cycle of abundance of monarchs at the Campus site as measured by the number of pupae which successfully eclosed. June peaks were produced by removing polistine wasps from the study site. 
Table 1 Comparison of the percentage of white monarchs at the Campus site in different years and at different times in each annual cycle

\begin{tabular}{|c|c|c|c|c|c|c|c|}
\hline \multirow[b]{2}{*}{ Year } & \multicolumn{2}{|c|}{ Nov-Dec } & \multicolumn{2}{|l|}{ Jan-Feb } & \multicolumn{2}{|c|}{ March-April } & \multirow{2}{*}{$\begin{array}{l}\text { Percentage } \\
\text { whites } \\
\text { for the } \\
\text { year }\end{array}$} \\
\hline & $\begin{array}{l}\text { Sample } \\
\text { size }\end{array}$ & $\%$ & $\begin{array}{l}\text { Sample } \\
\text { size }\end{array}$ & $\%$ & $\begin{array}{l}\text { Sample } \\
\text { size }\end{array}$ & $\%$ & \\
\hline $1972-73$ & 67 & $3 \cdot 0$ & 33 & $6 \cdot 1$ & 16 & 0 & $3 \cdot 4$ \\
\hline $1979-80$ & 43 & $4 \cdot 7$ & 103 & $2 \cdot 9$ & 18 & 0 & $3 \cdot 0$ \\
\hline $1980-81$ & 21 & $23 \cdot 8$ & 208 & $2 \cdot 4$ & 13 & 0 & $4 \cdot 1$ \\
\hline $1981-82$ & 177 & $3 \cdot 4$ & & & & & $3 \cdot 4$ \\
\hline $1982-83$ & 134 & $4 \cdot 5$ & 101 & $6 \cdot 0$ & 28 & $3 \cdot 6$ & 4.9 \\
\hline $1983-84$ & 76 & $5 \cdot 3$ & & & & & $5 \cdot 3$ \\
\hline $1984-85$ & 62 & $8 \cdot 1$ & 79 & $2 \cdot 5$ & & & $5 \cdot 0$ \\
\hline $1985-86$ & 145 & $4 \cdot 8$ & 39 & $5 \cdot 1$ & & & 4.9 \\
\hline $1986-87$ & 212 & $5 \cdot 4$ & 132 & $3 \cdot 8$ & 20 & $5 \cdot 0$ & $4 \cdot 9$ \\
\hline $1987-88$ & 146 & $1 \cdot 4$ & 732 & $6 \cdot 3$ & 145 & $3 \cdot 4$ & $5 \cdot 2$ \\
\hline $1988-89$ & 1068 & $8 \cdot 4$ & 462 & $4 \cdot 5$ & & & $7 \cdot 3$ \\
\hline Total & 2151 & $6 \cdot 6$ & 1889 & 4.9 & 240 & $2 \cdot 9$ & \\
\hline
\end{tabular}

infrequently seen outside of this period on the island of Oahu.

The proportion of whites has slowly increased at the campus site since the first estimate of their frequency on Oahu by Mitchell (1966) (fig. 2).
A weighted regression indicates that the slope of the points for 1965 through 1987 is significantly different from 0 , as are the slopes for the periods 1972 through 1987, and 1979 through 1987 (table 2).

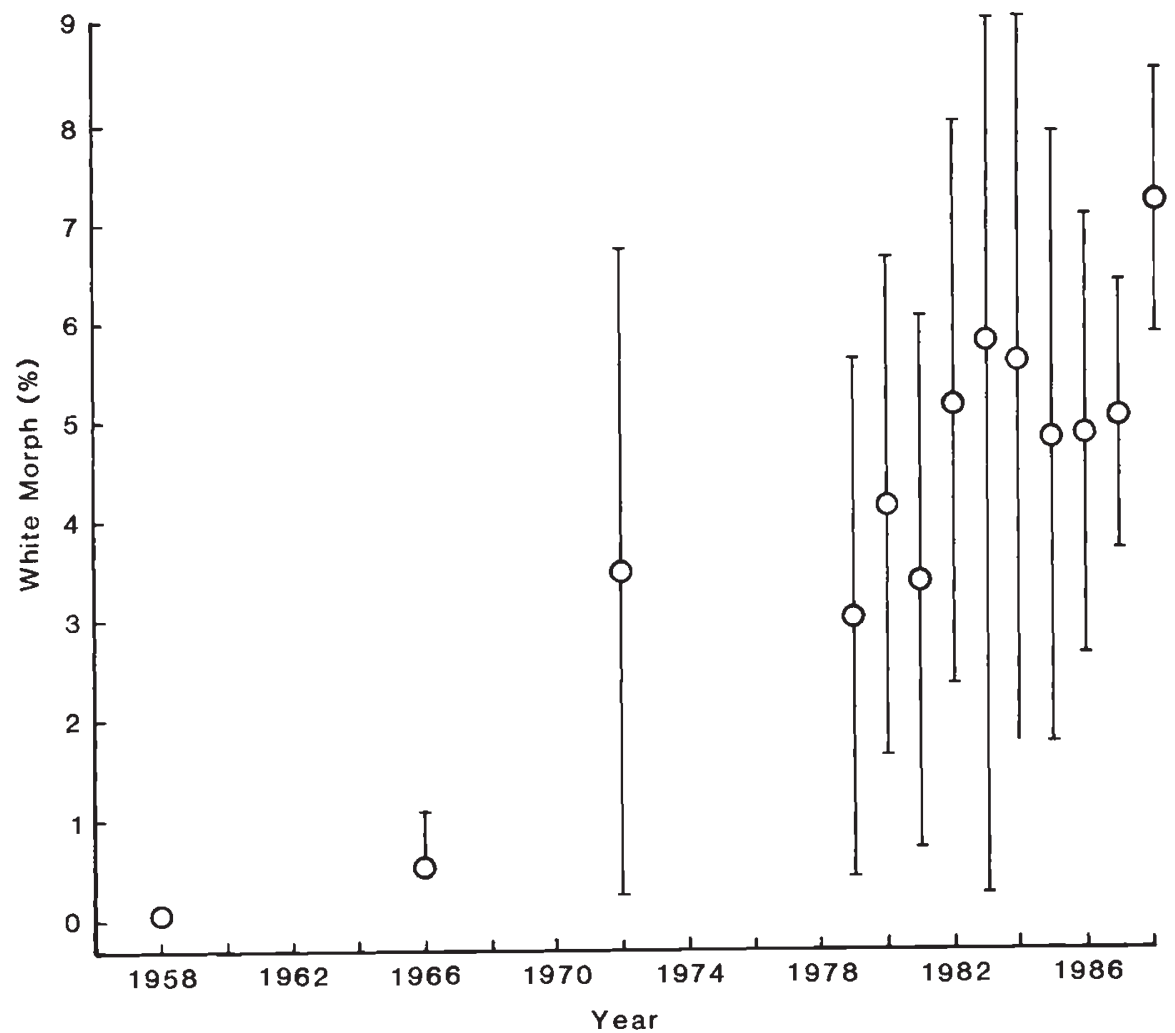

Figure 2 The increase in the proportion of white monarchs (with 95 per cent confidence intervals) as measured by the percentage of whites emerging from pupae collected on campus each year. The 1965 data point is from Mitchell (1966); the 1958 point reflects the fact that white monarchs were not reported in an extensive monograph on Hawaiian insects published by Zimmerman (1958). 
Table 2 Regression analysis of the relationship between the proportion of whites in the campus population and time. The " $t$ " value is the test of the significance of the slope value, $H_{0} B=0$. Each point estimate of the frequency of whites was weighted by its sample size for the regression analysis

\begin{tabular}{lllllr}
\hline $\begin{array}{l}\text { Time } \\
\text { interval }\end{array}$ & Intercept & Slope & $\begin{array}{l}\text { s.e. of } \\
\text { slope }\end{array}$ & \multicolumn{1}{l}{$\boldsymbol{l}$} \\
\hline $1965-87$ & -4.03 & 0.00206 & 0.00021 & 9.67 & $<0.001$ \\
$1972-87$ & -2.71 & 0.00139 & 0.00046 & 2.98 & 0.018 \\
$1979-87$ & -3.24 & 0.00165 & 0.00065 & 2.53 & 0.039 \\
\hline
\end{tabular}

There are no detectable seasonal differences in the proportion of whites in the population. The percentage of whites from the campus site (table 1) was compared among three time intervals spanning the annual cycle using a randomized blocks ANOVA. Different years were treated as blocks and two month periods of the annual cycle (NovDec, Jan-Feb, March-April) were the treatments/time intervals. The percentages were weighted by the sample size and subjected to an arcsin transformation. Data for 1981-82 and 1983-84 were omitted due to the incompleteness of records in those years. There were no significant differences in the proportion of whites in the different intervals, even though in some years the proportion of whites in the last two-month interval was zero. Deletion of the high Nov-Dec. 1980 value did not alter the conclusion that there is no significant difference among seasons. The proportion of whites in the two sexes is not significantly different.

The proportion of whites at eclosion does not differ among sites, based on a randomized blocks ANOVA of four sites (Campus, Kuliouou, Nanakuli and Waimanalo) over four time periods (table 3).

The proportion of whites at eclosion was generally lower than the proportion of whites in the population of flying adults captured over the same period at the same site (table 4). The flying adults were of a range of ages, but on average were older than the newly emerged butterflies; some had undoubtedly just emerged while others, judging from the loss of scales and wing damage, were probably weeks or months old. The number of recaptures was insufficient to estimate the average age of the individuals in the flying populations.

The fruit and insect eating birds Pycnonotus jocosus and Pycnonotus cafer (bulbuls) were observed attacking monarchs at all sites on Oahu. They took larvae and some pupae from the branches and undersides of milkweed leaves and also attacked adults that were resting, ovipositing
Table 3 Comparison of the percentage of white monarchs at emergence at four sites on Oahu

\begin{tabular}{llrl}
\hline \multirow{2}{*}{ Site } & Date & $\begin{array}{l}\text { Sample } \\
\text { size }\end{array}$ & $\begin{array}{l}\text { Percentage } \\
\text { white }\end{array}$ \\
\hline Campus & Jan-Feb 1988 & 732 & $6 \cdot 3$ \\
& Mar-Apr 1988 & 145 & $3 \cdot 4$ \\
& Nov-Dec 1988 & 1068 & $8 \cdot 4$ \\
Nanakuli & Jan-Feb 1989 & 462 & $4 \cdot 5$ \\
& Jan-Feb 1988 & 6 & 0 \\
& Mar-Apr 1988 & 114 & $4 \cdot 0$ \\
& Nov-Dec 1988 & 21 & $4 \cdot 8$ \\
Kuliouou & Jan-Feb 1989 & 29 & $6 \cdot 9$ \\
& Jan-Feb 1988 & 34 & $2 \cdot 9$ \\
& Mar-Apr 1988 & 17 & 0 \\
& Nov-Dec 1988 & 349 & $4 \cdot 0$ \\
& Jan-Feb 1989 & 307 & $8 \cdot 8$ \\
Waimanalo & Jan-Feb 1988 & 125 & 0 \\
& Mar-Apr 1988 & 65 & $7 \cdot 1$ \\
& Jan-Feb 1989 & 56 & $3 \cdot 6$ \\
\hline
\end{tabular}

Table 4 Comparison of the proportion of white monarchs among newly emerged adults and among populations of flying adults of unknown but greater age, collected at the same site during the same two month period. The percentage white at emergence is significantly different from the percentage white flying by a Wilcoxon signed-rank test, $P<0.05$

\begin{tabular}{|c|c|c|c|c|}
\hline & \multicolumn{2}{|c|}{$\%$ White emerged } & \multicolumn{2}{|c|}{$\%$ White flying } \\
\hline & $\begin{array}{l}\text { Sample } \\
\text { size }\end{array}$ & $\%$ & $\begin{array}{l}\text { Sample } \\
\text { size }\end{array}$ & $\%$ \\
\hline \multicolumn{5}{|l|}{ Campus } \\
\hline Jan-Feb 1988 & 732 & $6 \cdot 3$ & 125 & $11 \cdot 2$ \\
\hline Mar-Apr 1988 & 145 & $3 \cdot 4$ & 31 & $9 \cdot 7$ \\
\hline Nov-Dec 1988 & 1068 & $8 \cdot 4$ & 99 & $7 \cdot 1$ \\
\hline Jan-Feb 1989 & 462 & $4 \cdot 5$ & 108 & $10 \cdot 2$ \\
\hline \multicolumn{5}{|l|}{ Nanakuli } \\
\hline March 1988 & 114 & $4 \cdot 4$ & 90 & $11 \cdot 1$ \\
\hline Nov-Dec 1988 & 21 & $4 \cdot 8$ & 65 & $6 \cdot 2$ \\
\hline Jan-Feb 1989 & 29 & $6 \cdot 9$ & 176 & $8 \cdot 0$ \\
\hline \multicolumn{5}{|l|}{ Kuliouou } \\
\hline Jan-Feb 1988 & 34 & $2 \cdot 9$ & 37 & $8 \cdot 1$ \\
\hline Mar-Apr 1988 & 17 & 0 & 11 & $18 \cdot 2$ \\
\hline Nov-Dec 1988 & 349 & $4 \cdot 0$ & 51 & $5 \cdot 9$ \\
\hline Jan-Feb 1989 & 307 & $8 \cdot 8$ & 247 & $4 \cdot 5$ \\
\hline \multicolumn{5}{|l|}{ Waimanalo } \\
\hline Nov-Dec 1988 & 125 & 0 & 33 & $3 \cdot 0$ \\
\hline Jan-Feb 1989 & 56 & $3 \cdot 6$ & 286 & $1 \cdot 0$ \\
\hline \multicolumn{5}{|l|}{ Punaluu } \\
\hline Nov-Dec 1988 & 75 & $1 \cdot 3$ & 39 & $5 \cdot 1$ \\
\hline
\end{tabular}

or moving through the bushes. They rarely attempted to attack monarchs in flight. Captured monarchs were usually carried to the ground or a roof, where the birds broke off the wings before 
flying away with the body. The wings were collected from the ground and the proportion of white wings calculated. It was assumed that all such wings were the result of bulbul predation. Only 2 per cent of 100 wings collected at all the sites in 1987-88 were white, whereas 4.6 per cent of the butterflies which were sampled on eclosion were white in the same year. In $1988-89,0.9$ per cent of 107 wings collected at all sites were white whereas 6.6 per cent of all butterflies were white in the same year. The $1988-89$ results indicate a significantly lower proportion of whites in the wing collection than in the newly eclosed sample (Fisher's exact $P=0.006$ ), but the $1987-88$ data do not show a significant difference in the proportion of whites in the two samples $(P=0 \cdot 17)$. It is recognized that these data are very sensitive to assumptions about the randomness and thoroughness of the collection. In summary, the results suggest that the bulbuls may be causing a higher rate of mortality among the orange morphs than among the white morphs.

A high frequency of the white morph is evidently unique to Oahu. No whites were found on the islands of Maui (June 1988), Kauai (March 1989) and Hawaii (July 1989). Sample sizes were 97,106 and 42 respectively. Significantly, there are no bulbuls on any of these islands (S. Conant, personal communication, Univ. Hawaii).

\section{DISCUSSION}

There has probably been a low frequency of white monarchs in Hawaii for some years. A white monarch labelled "Hawaii, Palmer" was received in the mid 1890 s by the Rothschild collection (British Museum, Natural History) (Vane-Wright, 1986). J. Beardsley (personal communication, Univ. Hawaii) observed a white monarch in Haleiwa, Oahu, Hawaii in 1962 and Mitchell (1966) reported that in a collection of 600 monarch pupae made on Oahu in 1965, he observed three white individuals. By 1972 the percentage of whites in a collection made on the Manoa campus, University of Hawaii, was $3 \cdot 2$ per cent; substantially higher than Mitchell's figure (Stimson and Meyers, 1984). Since the early 1970 s the proportion of whites on the campus has slowly increased to about 5 or 6 per cent (fig. 2, table 2) and similar percentages can be found in other areas of Oahu. This increase has occurred despite the fact that each year the population apparently becomes very small during the summer and autumn months, presenting the possibility that the white allele (Stimson and
Meyers, 1984) could be lost or greatly reduced in frequency due to genetic drift. However, even at 2.9 per cent whites in the population (MarchApril, table 1), the proportion of white alleles in the population would be $0 \cdot 17$, and at this level it would seem unlikely that the allele would be lost.

The temporal increase in the proportion of whites (fig. 2) is consistent with the observation that white monarchs apparently survive predation better than orange individuals, as indicated by the higher proportion of whites in the flying population than in the contemporaneous emerging population (table 4). The higher survival of whites is also suggested by the observation that white wings constitute a small fraction of all wings collected during the 1987-88 and 1988-89 seasons.

Bulbuls have frequently been observed capturing larvae and attacking adult monarchs, and may be an agent in the increase in the proportion of the white morph. These birds were released from captivity in 1965 and 1966 in Honolulu (Berger, 1975; Williams, 1983) and since then have increased rapidly in abundance on Oahu (Van Riper et al., 1979; Williams and Giddings, 1984). They are now probably the commonest insectgleaning bird at low elevations, and probably the only one capable of taking an insect as large as a monarch. The birds do not find the monarchs to be distasteful and can be seen hunting near Calotropis gigantea. Most of their attacks occur from perches within the milkweed bushes on monarchs as they feed, oviposit or rest on the bushes. The higher survival of whites could be due to either apostatic selection by these birds or due to crypsis. The white monarchs may be less conspicuous to these birds than orange individuals because whites more closely match the white pubescence of the milkweed leaves or are inconspicuous against the patches of light shining through the foliage. The applicability of the apostatic selection and crypsis hypotheses cannot be determined at this point.

Two additional points suggest that bulbuls are the cause of the increase in the proportion of white individuals. First, the increase in the frequency of white individuals roughly coincides with the date of release of bulbuls from captivity. The first quantitative estimate of the proportion of whites on Oahu (Mitchell, 1966) is for late 1965 and the first reports of bulbuls was for autumn of that year, so Mitchell's estimate is essentially a pre-bulbul estimate, and subsequent increases may represent the influence of bulbuls. Second, the islands which lack established bulbul populations and have been 
sampled for white monarchs evidently also lack or have low frequencies of whites.

These lines of evidence suggest that selective predation by bulbuls has probably been the cause of the development and increase in the frequency of the white morph. The high predation rate is in turn traceable to the palatability of the monarchs which is either a result of the low cardiac glycoside levels in the insects or the tolerance of bulbuls for this chemical. These alternatives cannot as yet be separated.

Acknowledgements We wish to thank Dr Christine Simon and Linda Meyers for assistance in collecting and for commenting on the manuscript and Dr R. I. Vane-Wright for commenting on the manuscript. We also thank Patrick Conant and Dr John Stark for assistance in making collections on Maui and Kaui and Dr Marshall Johnson for advice.

\section{REFERENCES}

ACKERY, P. R. AND VANE-WRIGHT, R. I. 1984. Milkweed butterflies, Their Cladistics and Biology. British Museum of Natural History, London, $425 \mathrm{pp}$.

BERGER, A. 1975. Red-whiskered and red-vented Bulbuls on Oahu. The Elepaio, 36, 16-19.

ETCHEGARAY, J. B. AND NISHIDA, T. 1975. Reproductive activity, seasonal abundance and parasitism of the monarch butterfly, Danaus plexippus (Lepidoptera: Danaidae) in Hawaii. Proc. Hawaiian Ent. Soc., 22, 33-39.

GEROULD, J. H. 1923. Inheritance of white wing color, a sexlimited (sex-controlled) variation in yellow pierid butterflies. Genetics, 8, 495-551.

GORDON, I. J. 1987. Natural selection for rare and mimetic colour pattern combinations in wild populations of the diadem butterfly, Hypolimnas misippus L. Biol. J. Linn. Soc., $31,1-23$.
KETTLEWELL, H. B. D. 1955. Selection experiments on industrial melanism in the Lepidoptera. Heredity, 9, 323-342.

mitchell, w. 1966. Note. Proc. Hawaiian Ent. Soc., 14, 129.

OWEN, D. F. AND CHANTER, D. O. 1968. Population biology of tropical African butterflies. 2. Sex ratio and polymorphism in Danaus chrysippus L. Rev. Zool. Bot. Afr., Bruxelles, 78, 81-97.

OWEN, D. F. AND CHANTER, D. O. 1971. Polymorphism in West African populations of the butterfly, Acraea encedon. $J$. Zool., Lond., 163, 481-488.

PARSONS, J. A. 1965. A digitalis-like toxin in the monarch butterfly Danaus plexippus L. J. Physiol, Lond., 178, 290304.

REICHSTEIN, T., EUW, J. V., PARSONS, J. A. AND ROTHSCHILD, M. 1968. Heart poisons in the monarch butterfly. Science, $161,861-866$.

SEMBLE, D. T. 1980. Bioecology of some Trichogramma spp. on Oahu, Hawaii. Ph.D. Dissertation, University of Hawaii, Honolulu.

SMITH, D. A. S. 1973. Negative non-random mating in the polymorphic butterfly Danaus chryssippus in Tanzania. Nature, 242, 131-132.

SMITH, D. A. S. 1975. Genetics of some polymorphic forms of the African butterfly Danaus chrysippus L. (Lepidoptera: Danaidae) Ent. Scand. 6, 134-144.

STIMSON, J. S. AND MEYERS, L. 1984. Inheritance and frequency of a color polymorphism in Danaus plexippus (Lepidoptera: Danaidae) on Oahu, Hawaii. J. Res. Lepidoptera, 23, 153-160.

VAN RIPER, C., VAN RIPER, S. G., AND BERGER, A. J. 1979. The Red-whiskered Bulbul in Hawaii. Wilson Bull., 91, 323-328.

VANE-WRIGHT, R. I. 1986. White monarchs. Antenna, 10,117118.

WILliamS, R. N. 1983. Bulbul introductions on Oahu. The Elepaio, 43, 89-90.

WILLIAMS, R. N. AND GIDDINGS, L. V. 1984. Differential range expansion and populations growth of Bulbuls in Hawaii. Wilson Bull., 96, 647-655.

ZIMMERMAN, E. C. 1958. Insects of Hawaii, Vol. 7: Macrolepidoptera. University Press of Hawaii, Honolulu. 